\title{
Artigos
}

\author{
Claudia Fonseca
}

Universidade Federal do Rio Grande do Sul

\section{Mães "abandonantes": fragmentos de uma história silenciada}

\begin{abstract}
Resumo: Inspirado nos relatos dos membros de uma associação brasileira de filhos adotivos, este artigo propõe rastrear pistas sobre as mulheres que deram seus filhos em adoção em meados do último século. Juntando evidências fragmentadas - nas entrevistas com os adotados, nas cartas no site da associação, nos processos jurídicos do Arquivo Público do Estado do Rio Grande do Sul, nos relatórios da Santa Casa de Misericórdia de Porto Alegre, nas informações sumárias fornecidas hoje por instituições filantrópicas que acolhiam gestantes solteiras décadas atrás -, esta análise procura responder a duas perguntas levantadas pelos próprios adotados: por que eles foram dados em adoção? E por que os detalhes da adoção foram sistematicamente silenciados pelos pais adotivos, pelos intermediários e pelas autoridades estatais? O material sugere diversas possibilidades para explicar a entrega de uma criança em adoção no contexto brasileiro dos anos 1950-1970: a falta de autonomia legal e econômica das mulheres, uma moralidade sexual repressiva e a instabilidade geográfica e conjugal associada à pobreza. Ao mesmo tempo, as próprias dificuldades de encontrar informações sobre as mulheres "abandonantes" daquela época levantam hipóteses sobre as disputas institucionais (entre pais adotivos, serviços filantrópicos e juizados) que criaram um silêncio em torno desse momento da evolução da adoção legal no Brasil.
\end{abstract}

Palovras-chave: expostos; maternidade; adoção; mães abandonantes.

Copyright (c) 2012 by Revista Estudos Feministas.

\section{Ponto de partida: o "mistério" da adoção}

Sônia conta que desde a primeira infância suspeitava ser "apenas" a filha adotiva de seus pais. Mas quando a conheci em julho de 2007, fazia menos de um ano que tinha confirmado sua suspeita. Eu tinha ouvido a história de sua adoção primeiro de uma tia, depois dos próprios pais. Cinquenta anos atrás, a cada domingo, 0 pai de Sônia, padeiro de uma cidade gaúcha na fronteira com a Argentina, levava o que sobrava da semana - pão, alguns bolos e quitutes - para um orfanato local. Em uma dessas visitas ele tinha cruzado com a recém-nascida Sônia 
e foi amor à primeira vista. Em questão de dias, ele e sua mulher, na qualidade de padrinhos, tinham batizado a criança na igreja da cidade. Pouco depois, eles tiraram os papéis oficiais da adoção. Cidadão respeitado do local, seu pai "conhecia todo o mundo". Usando as suas conexões, ele acompanhou o oficial de justiça quando foi à casa da mãe biológica de Sônia para conseguir sua assinatura nos documentos de adoção. A mulher, ele disse, era jovem, legalmente casada (como se confirma na certidão original de nascimento de Sônia) e morava numa casa "boa". A aparentemente confortável situação de sua mãe de origem apenas deixa Sônia mais ansiosa para saber por que ela foi dada em adoção.

Agora que tinha confirmado que era, de fato, uma filha adotada, entender as circunstâncias de seu abandono virou obsessão. Sônia queria saber não somente quem era aquela jovem senhora, mas que circunstâncias a tinham levado a assinar o consentimento para a adoção, apesar de ser casada com o pai de seu bebê. Queria saber se sua mãe tinha outros filhos, se existiam irmãos ou sobrinhos que seriam de "meu sangue". Essa procura não representava para Sônia um repúdio de sua família adotiva. Pelo contrário, ela tinha sido muito próxima de seu (único) irmão menor, morto de doença no início da vida adulta. Como Sônia repetia sem parar, ela simplesmente "queria entender".

Foi durante uma pesquisa inicial realizada numa associação de filhos adotivos - pessoas já adultas - em busca de suas origens que conheci Sônia e outros adotados com preocupações semelhantes. As reuniões ocorriam em Porto Alegre, mas o site da associação na internet reúne centenas de histórias de toda parte do território nacional. Tem cartas de adotados (adultos), mães e irmãos "de sangue", e algumas mães adotivas - todos em busca de dados (e vínculos) que foram apagados pela adoção. Suas idades se estendem de 19 a 73, mas a maioria nasceu nas décadas de 1960 e 1970. Em 2009, essas pessoas viram sua causa reconhecida pela "Nova Lei de Adoção", uma emenda ao Estatuto da Criança e do Adolescente que, seguindo o exemplo de outros países, dá ao adotado "acesso irrestrito" ao processo no qual a medida de adoção foi aplicada (art. 48). Entretanto, a lei parece ajudar pouco, pois, como veremos, os obstáculos ao desvelamento do "mistério" da adoção - a descoberta dos motivos que levaram milhares de mulheres nessas três décadas a dar um filho em adoção - vão além da ordem legal.

Instigada pelos relatos dos adotados, parti à procura de qualquer material que pudesse fornecer pistas sobre suas mães "abandonantes". Descobri que não existem registros que permitam contar uma história linear. Tive que recompor 
1 Maria Luiza MARCILIO, 1997; e Renato Pinto VENÂNCIO, 2010.

${ }^{2}$ Sueann CAULFIELD, 2000; Martha ESTEVES, 1989; entre outros.

${ }^{3}$ Domingos ABREU, 2002. as circunstâncias dessa época a partir de fragmentos garimpados na memória dos adotados, nas cartas no site, nos processos jurídicos do Arquivo Público do Estado do Rio Grande do Sul, nos relatórios da Santa Casa de Porto Alegre, nas informações sumárias fornecidas hoje por instituições que acolhiam gestantes décadas atrás etc., além de apoiarme nos achados de colegas que pesquisam sobre esse período. Nos parágrafos a seguir, se não consegui fornecer os detalhes precisos que Sônia queria, pelo menos pretendo dar início ao resgate de uma história coletiva, própria a essa época, de mulheres que estavam negociando os difíceis termos de uma maternidade tida como fora de lugar.

\section{Uma lacuna na historiografia}

Existe no Brasil uma prolixa historiografia sobre crianças abandonadas da época colonial até o fechamento das últimas "rodas dos expostos". Graças aos esforços de uma geração de pesquisadores, visualizamos sem muita dificuldade a "roda", essa caixa giratória do tamanho de um berço implantada em boa parte dos hospitais públicos para garantir o total anonimato de quem queria se livrar de um recém-nascido. ' Mas o interesse no abandono vai minguando à medida que os anos avançam, parecendo vaporizar por completo com o fechamento das últimas rodas - 1938 no Rio, 1940 em Porto Alegre, 1950 em São Paulo e Salvador. Em todo caso, a ênfase desses estudos é geralmente nas crianças e na institucionalização delas. Para chegar mais perto das próprias mulheres, temos os processos jurídicos iniciados por "meninas perdidas" e donzelas desonradas, ${ }^{2}$ mas falta o elo que ligaria esse material à eventual colocação da criança numa família substituta.

Antes dos anos 1980, nem os processos jurídicos sobre adoção trazem muitas respostas. A adoção, instituída pela primeira vez no Código Civil de 1917, continuava a ser, durante toda a primeira parte do século $X X$, um procedimento administrativo que podia ser realizado num cartório de registro civil. Os Juizados de Menores que surgiam em grandes cidades desde os anos 1920 podiam ser chamados para oficializar o processo. Mesmo assim, não teriam recursos para conduzir investigações ou supervisionar a transferência de crianças. Apenas legalizavam arranjos que tinham sido decididos pelas partes envolvidas.

Contudo, a grande maioria das colocações de crianças não chegava aos tribunais. Estima-se que $80 \%$ a $90 \%$ das adoções não foram vistas nem registradas pelas autoridades oficiais. ${ }^{3} \mathrm{Na}$ época, a burocracia estatal ainda não tinha penetrado de forma eficaz no cotidiano da população. Muitas pessoas adquiriam uma certidão de 
nascimento apenas quando entravam no primeiro ano da escola ou quando faziam seu serviço militar. Nessas circunstâncias, o escrivão de cartório teria pouca possibilidade de verificar quem de fato dera à luz a criança. Os pais adotivos podiam simplesmente chegar ao cartório (tal como quaisquer outros pais) e, com o apoio de duas testemunhas, registrar a criança como filho biológico. Esse procedimento, conhecido como "adoção à brasileira", era tecnicamente ilegal, tendo como pena dois a seis anos de reclusão, conforme o artigo 242 do Código Penal. Mas, no próprio artigo, havia um parágrafo sobre circunstâncias atenuantes - quando o "crime" era praticado "por motivo de reconhecida nobreza" -, o que reflete a tolerância generalizada pela prática.

Essa informalidade dos circuitos de adoção se destaca nas cartas que encontrei no site dos filhos adotivos. Nessas cartas, torna-se aparente como o adotado deve fazer um verdadeiro trabalho de detetive para reconstituir os "fatos" de seu nascimento. Em geral, sabe-se pouco sobre quem intermediou a adoção: podia ser "uma cabeleireira no bairro do Horto" (Belo Horizonte) , "a senhora Terezinha, na época proprietária da loja Mary Moda" (Uruguaiana) ou "uma senhora chamada Marlene que trabalhava com a irmã [da mãe biológica], na empacotadora de alho" (São Paulo). Em muitos casos, a mãe trabalhava como empregada doméstica e era através da patroa e das redes sociais desta que se escolhia uma família substituta para o bebê. Em outros, era a enfermeira do hospital ou a mulher do médico obstetra que se encarregava da criança. Na maioria dos casos, a entrega do bebê resultava numa adoção à brasileira que não deixava pista sobre a família de origem.

Algumas pessoas sabem que nasceram em determinada maternidade ou lar, mas nem esse dado facilita a busca. Como escreveu um rapaz, "Nasci no lar das mães solteiras em Porto Alegre-RS em [tal dia] de 1963. Já tentei de tudo, mas não consigo nenhuma resposta. Procurei o juizado da infância, mas nada". Os adotados que, em geral, já esbarraram na relutância dos seus pais adotivos em falarem do assunto, ficam perplexos quando as burocracias institucionais respondem a suas indagações com indiferença. Vide o caso de Moisés, nascido em Bebedouros, Alagoas, adotado em São Paulo: "Fui até no juizado de menores, mas sem resultado, pois me disseram que a busca deveria vir de ambas as partes". Laura, uma menina que hoje vive na França com seus pais adotivos, consegue uma amiga para traduzir sua frustração para a língua portuguesa: "Estive com os meus pais adotivos na minha cidade natal no dia do meu aniversário de 18 anos e lá tentamos saber um pouco mais da minha história, sem muito sucesso, pois o 
${ }^{4}$ Graças às pesquisas em domicílio realizadas pelas novas equipes de profissionais ligadas aos juizados, os arquivos judiciais se tornaram uma rica fonte de pesquisa, fornecendo a possibilidade de sistematizar dados dos anos 1980 para cá.
5 Lygia AYRES, 2008; e Maria Antonieta Pisano MOTTA, 2005. que me informaram é que eu não tinha o direito de olhar o meu próprio processo de adoção" (nascida em Vitória da Conquista, Bahia).

Os adotados têm dificuldade ainda maior em entender que, em muitos casos (talvez a maioria), simplesmente não existe registro de sua adoção. Não conseguem imaginar quão diferentes eram as circunstâncias trinta a quarenta anos atrás. É só no final dos anos 1970 que se inicia uma gradativa expansão da autoridade do Estado brasileiro nos procedimentos adotivos. ${ }^{4}$ É também nessa década que uma série de inovações sociais e tecnológicas tem início, transformando a maternidade. As políticas do planejamento familiar levam o conhecimento de tecnologias contraceptivas para dentro das famílias, provocando uma queda radical na taxa brasileira de fecundidade-de mais de seis filhos por mulher para os atuais dois filhos. Nos anos 1980, o movimento feminista, insuflado pela expansão de movimentos sociais, passa a abrir novos espaços para a mulher brasileira. 0 impacto da Lei do Divórcio, junto com a ampliação de oportunidades de emprego para mulheres, alimenta situações antes pouco comuns de autonomia feminina. $\mathrm{Na}$ década de 1990, junto com a Lei de Paternidade e campanhas para a "paternidade responsável", aparece uma nova tecnologia - o teste de DNA - aplicada especialmente nas investigações de paternidade. Finalmente, com a virada do milênio, uma série de políticas sociais - bolsa família, creches públicas - vem amparar "famílias em situação de vulnerabilidade", permitindo que mulheres sozinhas tenham a possibilidade de criar dignamente seus filhos.

As mudanças são tais que adentrar a experiência de uma mãe "abandonante" naqueles anos 1950 a 1970 justamente o período no qual os adotados encontram só imagens turvas e dados ausentes - exige grande esforço. Enfrentando esse desafio, propomos voltar agora a essas décadas ignoradas pela historiografia do "abandono" para, dando eco à exortação de Sônia, simplesmente tentar entender.

\section{A menoridade das mulheres}

A palavra "abandono" carrega conotações de uma rejeição emocional, como se a entrega do filho fosse uma escolha consciente das mães em questão. Hoje, pesquisadores enfatizam o quanto a mulher que consente dar o filho em adoção foi, ela mesma, "abandonada" pelo companheiro, pelos pais e pela sociedade. ${ }^{5}$ Enfatizase o fato de que, em tempos recentes, a maioria esmagadora de crianças adotáveis vem de famílias vivendo na miséria. 
${ }^{6}$ Ainda que seja sobre uma época mais recente, o estudo de Maria da Graça Maurer Gomes TURCK (1991, p. 114) traz casos semeIhantes sobre, por exemplo, uma mulher cujo marido ficou subitamente desempregado: "O que esta criança vai ter? vai viver na rua [...]. Como eu acho que meus filhos mais velhos têm chance de estudar, de ser alguém, eu não vou tirar eles do colégio pra esse pequeninho. Então eu estou fazendo este sacrifício para mim $[\ldots] "$.
Certamente há cinquenta anos, havia muitas famílias em que a margem de sobrevivência era tal que mais uma boca para alimentar representaria a ruína de todos. Lemos nas cartas no site histórias como a de um jovem recifense à procura de seu irmão dado em adoção. Quando sua mãe engravidou pela primeira vez, o pai dela mandou dar a criança "porque já tinha 7 filhos e não podia manter [mais um]. Com o coração [apertado] ela foi obrigada dar a criança recém-nascida". Mesmo mulheres mais velhas podiam se encontrar em situações insustentáveis. A morte ou doença do companheiro podia provocar uma crise de proporções dramáticas, obrigando a mãe a fazer uma escolha salomônica quanto a ficar ou não com todos os filhos. ${ }^{6}$

Chama atenção, entre os relatos no site de filhos adotivos, a ideia repetida de que as mulheres foram coagidas a abrir mão do filho. Muitas vezes é um filho subsequente, um que a mãe criou, que restitui a narrativa sobre esse irmão perdido. Contam como a criança foi "tirada" pelo pai (ou padrasto, ou tia) da gestante e entregue em adoção. A mulher - jovem e ainda dependente dos pais teria sido engravidada por um companheiro que não tinha nenhuma intenção de assumir o filho. Diziam-lhe que, se teimasse em ficar com a criança, seria expulsa de casa. Nessas circunstâncias, como ia ganhar a vida? Quem ia cuidar da criança? Na hora, a jovem não tinha armas para resistir às pressões e, já que o processo adotivo não deixava rastros (correndo por vias informais ou por burocracias pouco sistemáticas), tampouco teria como, num momento posterior, voltar atrás e recuperar o filho.

Não era diferente quando a menina já trabalhava como empregada. Como diz uma mineira que, ainda jovem, foi trabalhar em São Paulo: "Meus patrões resolveram doar meu bebê. Sem ter onde morar, sem dinheiro, menor de idade e com uma criança no braço não poderia ir para a rua, e não tive outra opção a não ser fazer o que eles queriam".

Mas seria um erro pressupor, numa projeção anacrônica da situação atual, que, naquela época, as mulheres que não viviam na extrema miséria tivessem o poder de tomar as decisões importantes de sua vida. A desvantagem legal da mulher fica escancarada num processo, encontrado nos arquivos públicos de Porto Alegre, em que consta um pedido de "dissolução" de adoção iniciado em 1964. Trata-se do caso de Regina, uma jovem (de 24 anos) oriunda de Santa Catarina que veio para o interior do Rio Grande do Sul casar-se com um viúvo, motorista de profissão, e com o dobro da idade dela. Não apreendemos nada nas folhas do processo sobre o relacionamento do casal, fora o nascimento de uma filha 
um ano depois do casamento. Mas cinco anos mais tarde, encontramos o marido internado no "nosocômio" de Porto Alegre, onde foi tratar um câncer de cérebro. Um dia antes de morrer, agindo por procuração, ele estabelece uma escritura pública dando sua filha em adoção a um casal que, pelos nomes e pelas idades, parecem ser irmã e cunhado dele. A justificativa é sumária: ele está morrendo, o casal não tem filhos e já existe uma relação de afeto entre a menina e os pais adotivos escolhidos pelo pai. O curioso no caso em questão é que Regina, a mulher do moribundo e mãe da criança, não aparece em lugar algum da escritura pública. Sem dúvida para simplificar o processo, nesse documento, seu marido se esquece de seu casamento religioso com Regina e se declara como "viúvo" (sem dúvida de um casamento anterior). Podemos intuir algo da oposição de Regina pelos acontecimentos subsequentes à morte de seu marido. Menos de três meses depois, tendo se casado em Florianópolis com um funcionário civil (dessa vez, apenas 17 anos mais velho que ela), ela entra com uma petição para desfazer a adoção. Apesar de seu novo marido não se manifestar na petição, podemos supor que essa mãe só se sentiu autorizada a reivindicar seus direitos maternos depois de, mais uma vez, adquirir o status de mulher casada.

De fato, diferente do que reza o senso comum, o status materno não era nada "evidente" nessa época de burocracia estatal incipiente. Tal fato explica os processos de investigação de maternidade desse período que encontramos nos arquivos públicos. Podiam ser movidos pelo próprio filho, como no caso de um homem deserdado por seu meio-irmão que o acusava de ser um "mero filho de criação". Sem certidão de nascimento e só com documento de identidade (com idade, segundo ele, falsa) estabelecido para servir no exército, o requerente, nesse caso, teve que mobilizar todos seus recursos para comprovar a filiação. Mas encontramos também investigações de maternidade movidas pela própria mulher para conseguir a guarda dos filhos depois de uma separação conjugal. Consideremos, por exemplo, o caso de Jacira, que procurava reaver suas três filhas que moravam então com o pai e a madrasta. Acontece que o ex-companheiro de Jacira tinha registrado as crianças, nascidas no decorrer dos anos 1950, só no nome dele. Quando confrontado pelo tribunal sobre essa estranha omissão do nome da mãe, o homem se defendeu dizendo que nunca tivera a intenção de negar a maternidade de sua mulher, que só tinha seguido as orientações do escrivão do cartório. Já que sua mulher era casada com outro homem, omitir o nome dela da certidão era a única maneira de impedir que o marido oficial assumisse a autoridade paterna sobre as filhas "adulterinas". 
${ }^{7}$ Mary del PRIORE, 2005.

${ }^{8}$ DÉCADA DE 50, 2006; e EMILINHA BORBA, 2011.
A ausência do nome materno estava explicada, mas ainda cabia comprovar quem era a mãe. Foi só graças a um documento resgatado na própria maternidade na qual tinha dado à luz que Jacira conseguiu fornecer a prova definitiva, convencendo o tribunal de sua relação com as próprias filhas.

Evidentemente, não era nada difícil apagar a participação da mãe do nascimento, mesmo quando todo o processo corria por vias oficiais. Também no Arquivo Público encontramos o caso de certo menino entregue com dois anos de idade aos seus pais adotivos pelo Serviço Social de Menores. Para que seus novos cuidadores pudessem adotá-lo legalmente, precisavam de uma certidão de nascimento. Bastou aos pais adotivos levarem duas testemunhas a um cartório de seu bairro para conseguir a documentação desejada. Nessa documentação constavam claramente todos os detalhes necessários: o nome do menino, nascido na Santa Casa de Porto Alegre em tal dia de 1951, de pai e mãe desconhecidos.

\section{Negociando uma gravidez extraconjugal}

Sabemos pelos historiadores que, desde os anos 1920, existia certa modernização das relações de gênero nas camadas cosmopolitas. ${ }^{7}$ Através de revistas e romances dirigidos ao público feminino, circulavam ideias sobre a mulher independente e as alegrias do amor romântico. Entretanto, ainda estávamos longe da revolução social. $O$ estigma de ser uma mãe solteira dando à luz uma criança fora do casamento era enorme, tanto nas camadas urbanas abastadas quanto em muitas famílias interioranas mais modestas. Tal fato torna compreensíveis as palavras de uma profissional administradora atual de um abrigo para mães solteiras com quem falei: "Anos 50 e 60? Não temos nenhum registro desse período. Houve um incêndio (pausa), é o que dizem. Mas pode ser que os arquivos foram 'sumidos'. Entende? As mulheres daquela época vinham justamente para esconder sua gravidez e o parto".

A história de Emilinha Borba, "Rainha do Rádio" durante os anos 1950, ilustra o clima da época. ${ }^{8}$ A cantora carioca gozava de enorme popularidade entre seus fãs. Tinha um apelo particular nas camadas modestas, que se identificavam com sua aparentemente pacata forma de viver a celebridade. Nas colunas que assinava na Revista do Rádio, sempre incluía referências a orações e suas idas à missa. Diferente de outras estrelas da época, usava roupas recatadas e evitava aparecer em desfile de Carnaval. Assim, o surgimento de um filho na sua vida - logo no auge da fama - está envolto em certo mistério. Ninguém soube de 
9 Joana Maria PEDRO et al., 2003, p. 72-73. uma gravidez, e, durante uma turnê no (então remoto) Sul do país, a cantora escreveu na sua coluna semanal que planejava adotar um pequeno sul-rio-grandense. A criança ganhou o nome Artur Emilio, incorporando já o nome do namorado com quem Emília se casaria poucos anos depois. O silêncio dos fãs (até hoje) é sinal de que Emilinha encontrou uma maneira ideal para driblar a moralidade conservadora da época e, sem estigma, ficar com seu bebê, fruto de uma relação extra(pré)conjugal.

Entretanto, essa moralidade podia fazer sérios estragos na vida de mulheres com menos recursos que Emilinha Borba, dando poucas alternativas à moça que enfrentava uma gravidez indesejada. O Brasil ainda era um país rural; a maioria da população vivia em cidades interioranas ou em vilarejos onde as línguas fofoqueiras estavam à espreita da mínima transgressão sexual. Saíam desses lugares as moças que comporiam o exército de empregadas domésticas da época. Migravam para cidades maiores, algumas já grávidas - expulsas de casa. Outras vinham embora para esconder de suas famílias e vizinhos a gravidez. Ainda outras, usufruindo da liberdade de sua nova autonomia, engravidavam na cidade. Consta nessas últimas histórias uma frase recorrente: "Meus pais não podiam saber".

A vergonha não se remetia à gravidez em si (afinal de contas, a maternidade era o destino de toda mulher) nem à solteirice em si (Emilinha podia ser admirada por, ainda solteira, adotar um filho). Era a combinação dos dois - a conotação de relações sexuais fora do casamento que suscitava escândalo. O remédio ideal para acabar com a vergonha pública era fazer com que o namorado assumisse legal e socialmente a paternidade. Mas não era o único remédio. A história de Ivonete, encontrada nos arquivos do fórum de Florianópolis pela historiadora Joana Pedro, " fala de o quanto a história de filhos "abandonados" é misturada a amores frustrados e ao drama do aborto. Em 1967, Ivonete ainda era menor quando começou um namoro com Jorge, um jovem militar. Apesar das advertências do pai da moça de que o soldado "deveria manter o máximo de respeito, pois a moça era órfã de mãe", Ivonete foi seduzida por promessas de casamento. Quando levou a notícia de sua gravidez para o namorado, contrário a suas expectativas, foi recebida não com alegria, e sim com a recomendação de que tomasse certa erva com conhaque.

Esse e outros estudos nos processos-crime do último século mostram como não era incomum o amante tomar a iniciativa de providenciar um aborto. Os estragos de uma tecnologia rudimentar - de instrumentos perfurantes e de "chás" altamente tóxicos - ficavam por conta da mulher. 
${ }^{10}$ PEDRO et al., 2003, p. 73.

\footnotetext{
${ }^{11}$ Ainda na década de 1980 pesquisas sugerem que até um quarto das mulheres que procuravam o juizado para entregar um filho em adoção não tinha informado o pai da criança quanto à gravidez (TURCK, 1991). Quando avisados quanto à gravidez, a maioria dos supostos pais mostrava indiferença, desconfiança ou simplesmente "sumia".
}

Nesse caso, Ivonete resistiu contra as pressões do amante na esperança sem dúvida de levá-lo ao altar. Resultado: o soldado mudou de tática. Com o apoio de seus familiares, afirmava que Ivonete não era ingênua nem inocente, que já tivera namorados antes dele e que o traía com outros soldados. Com isso, o advogado de defesa conseguiu inverter as acusações: "Acreditamos, em síntese que o [réu] foi vítima de sua ingenuidade, isto é, 'entrou de gaiato', razão pela qual pedimos justiça". ${ }^{10} \mathrm{~A}$ história de Ivonete não vai além da disputa sobre a responsabilidade de seu namorado. Tendo perdido seu pleito, parece que a moça foi morar com seu filho junto a uma tia, mas quem sabe se ficou com a criança.

A história de Ivonete não é muito diferente da de Mariana que nos foi contada pela patroa que intermediou a adoção de seus dois bebês. A moça, recém-chegada do campo para assumir o emprego de empregada doméstica, havia "escondido a barriga". Logo nos primeiros meses, conseguiu fazer uma visita à sua cidade natal para "conversar" com seu namorado, sem que seus pais soubessem da gravidez. Quando finalmente reconheceu que seu amante não ia assumir o filho, já era tarde para fazer um aborto. Alguns anos mais tarde, Mariana ficou grávida mais uma vez: "Aquela segunda vez, ela achava que realmente ia casar, mas não deu". Assim, entregou o segundo filho em adoção, assim como tinha feito com o primeiro, sem nunca cair na fofoca de sua cidade natal.

Sem dúvida, pesando na decisão de Mariana de não ficar com seus filhos, a decepção se somou às difíceis condições econômicas. Em todas as fontes consultadas, há histórias de mulheres que entregaram um filho em adoção porque, amarguradas pela experiência com 0 excompanheiro, não queriam ter nenhuma lembrança da relação. A história de Tatiana acena para essa possibilidade: "Meu nascimento deu-se do encontro de minha mãe com um homem que dizem ser de descendência alemã, de boas condições financeiras e que possuía uma plantação de rosas, mas ele próprio não sabia da gravidez". Quiçá essa mãe quisesse evitar uma possível humilhação. (Tantas vezes aprendemos que, quando avisado da gravidez, o "suposto pai" mostra indiferença, desconfiança ou simplesmente "some". ") Mas também pode ser que ela estivesse procurando uma maneira, por mais radical que fosse, de se prevenir contra qualquer interferência de seu ex-namorado nas decisões que devia tomar.

Sem dúvida, muitas meninas, tal como Ivonete, Juliana ou a mãe de Tatiana, tiveram namorados mal escolhidos. Esses vinham de todas as classes, mas chama atenção a proporção de homens com profissões que 
${ }^{12}$ Claudia FONSECA, 2005.

implicavam certa mobilidade - caminhoneiro, motorista, soldado, cobrador de ônibus inter-regional etc., fato que só alimenta as incertezas. Como diz Luana na sua carta no site, "O mais triste de tudo é que não sei ao menos se minha mãe sabia o nome verdadeiro dele, visto que, mulherengo que era, costumava mentir seu nome e dados de sua vida com freqüência". Podiam disfarçar a profissão ("trabalhava como carroceiro, mas provavelmente não contou isso à minha mãe") e o fato de já estar vivendo maritalmente com outra mulher e filhos.

Podemos supor que esses homens faziam tudo para não serem identificados como autores de alguma gravidez. ${ }^{12}$ Quando não tinham como evitar essa identificação, podiam empurrar a mulher para provocar um aborto. Quando todas as outras táticas falhavam, podiam se prevenir contra responsabilidades futuras (um processo por pensão alimentícia, por exemplo), subtraindo o bebê da mulher para entregá-lo em adoção. Como diz Luana, "Já ouvi conversas de que [meu pai antes de me dar em adoção] teria ficado comigo contra a vontade [da minha mãe] e posteriormente dito que eu havia morrido". Em outra carta, aprendemos a saga de Francisca, recém-chegada do Ceará à capital paulista, que foi engravidada pelo vizinho. Depois do parto, os avós paternos "tiraram" o bebê dela, alegando que ela "não tinha nem onde morar e muito menos condições de criá-lo". Se Francisca entendeu originalmente que a criança seria criada pela família paterna, foi logo desenganada. "Não ficaram com a criança porque [o pai] era noivo na Bahia e [...] a noiva dele não aceitou a criança". Assim, o bebê passou de um "casal de enfermeiros", que tampouco pôde ficar com ele, para outros cuidadores, até a mãe perder sua filha completamente de vista.

A ânsia masculina de apagar qualquer traço de sua responsabilidade sem dúvida aumenta com a diferença de classe entre o homem e a mulher gestante. Há diversos relatos sobre a funcionária de certo comércio engravidada pelo filho do dono ou da empregada doméstica que engravidou do próprio patrão. Nesses casos, convencer a mulher a doar seu filho anonimamente em adoção seria quase tão eficaz quanto convencê-la a fazer um aborto.

No caso de Lúcia, uma filha adotiva que entrevistei pessoalmente, encontramos uma pista final para pensar como, na negociação de uma gravidez extraconjugal, as mulheres sofriam sérias desvantagens. Lúcia conta que sua família adotiva sempre se referia à mãe como "aquela vagabunda" ou "prostituta" que tinha abandonado sua filha sem olhar para trás. Quando, já adulta, Lúcia estabeleceu contato com uma irmã de sua família original, 
${ }^{13}$ Maria Angelica MOTTA-MAUÉS, Daniele IGREJA e Luisa DANTAS, 2009. ouviu outra história. A mãe tinha sofrido muito com a separação e tinha tentado diversas vezes (em vão) fazer contato com a filha. Por outro lado, havia certa suspeita sobre a identidade do homem, genitor da criança. A mãe de Lúcia, sozinha e sem condições para sustentar o bebê, tinha dado à luz logo na época em que o casal que viria a adotar Lúcia estava se casando. O noivo a princípio não queria ficar com o bebê porque não queria nada com "aquela mulher" (mãe do bebê), que já conhecia por outras vias. Porém, diante das pressões de sua esposa e de seus próprios pais, ele teve que ceder. Sabendo que seu pai adotivo tinha sido um notório mulherengo, Lúcia juntou os pedaços dessa história e chegou a certas conclusões. Sua mãe não tinha feito um aborto nem tinha dado anonimamente a filha em adoção. Mas o pai tinha conseguido ficar com o fruto de uma aventura sexual, sem nunca mais ter que se preocupar com a mulher que gerou a criança.

\section{O dilema dos pais adotivos}

Os pais adotivos daquela época, via de regra, escondiam do filho o fato de que ele era adotado. Há ampla razão para acreditar que eram motivados, em grande medida, pelo desejo de proteger seus filhos contra a discriminação social e legal. Devemos lembrar que, durante os anos 1950 a 1970, muitas unidades domésticas ainda incluíam "filhos de criação", jovens de origem pobre que em troca de casa, comida e alguma educação - pegavam nas lides do serviço doméstico. ${ }^{13}$ Embora esses pequenos criados pudessem desfrutar de certos privilégios da infância, ninguém esperava que fossem tratados em pé de igualdade com os filhos da família. Além do mais, havia uma forte crença de que, em última instância, o "sangue" determinava o caráter de um indivíduo. No clima eugenista da época, imaginar que o adotado fosse filho ilegítimo de uma empregada doméstica ou mesmo que tivesse nascido numa família de poucos recursos podia ser razão suficiente para considerá-lo como intrinsecamente inferior às crianças legítimas de condição social mais elevada.

A Lei de Adoção daquela época (Lei n. 3.133, de 1957) consagrava essas desigualdades. A adoção ainda era um contrato revogável, cujos efeitos não se estendiam para além da relação entre os filhos e seus pais. Se os pais já tivessem filhos antes da adoção, o filho adotado não herdava nada; se tivessem um bebê depois, o filho adotado tinha direito a apenas metade da parte reservada a um filho biológico. Durante os anos 1950, legisladores começaram a cultivar a ideia de "proteção da criança", justificando assim emendas ao Código Civil que tornassem 
14 FONSECA, 2009.

15 E. Wayne CARP, 1998; FONSECA, 2009; Judith MODELL, 2002; e Françoise-Romaine OUELLETTE, 2009.

${ }^{16}$ Cecília COSTA, 1988, p. 111. a adoção mais acessível. Contudo, até o Código de Menores (1979), crianças adotadas nunca poderiam ter mais que um precário pertencimento legal em suas novas famílias. Os pais que queriam conferir ao seu filho adotivo status igual ao dos filhos nascidos na família tinham só uma alternativa: esconder de todos o fato da adoção.

Entretanto, conforme os filhos adotivos que entrevistei, mesmo quando o fato da adoção já era de conhecimento público, seus pais adotivos relutavam em discutir o assunto com eles. Resistiam ainda mais ao fornecimento de qualquer detalhe identificador que pudesse proporcionar um contato com a família de origem. Era evidente que tinham muito medo que esse tipo de contato pudesse redundar na perda do filho. Imaginavam o pior: se a mãe original não tentasse levá-lo embora, o próprio filho poderia fugir para ir atrás dela. O assunto era tão delicado que muitos dos entrevistados, para não magoar seus pais adotivos, esperaram que esses falecessem antes de iniciar sua busca de parentes consanguíneos.

As crenças e os valores familiares que levam pais adotivos em todo o mundo ocidental a rechaçar qualquer reconhecimento de possíveis outros pais de seu filho já foram alvo de muita reflexão. ${ }^{14}$ Salienta-se o fato de que, nos Estados Unidos ou na França, por exemplo, não são as mães de nascimento e sim os próprios pais adotivos que insistem no "segredo de justiça", isto é, o "chaveamento" dos arquivos que impede $o$ acesso de qualquer pessoa (incluindo as partes mais envolvidas) à informação sobre um processo adotivo já realizado. ${ }^{15}$ No Brasil como em outros lugares, a diferença de classe entre as famílias doadora e recebedora da criança é sem dúvida um fator complicador. Explica, por exemplo, por que certo pai adotivo resiste com tanta veemência à "busca" iniciada por sua filha: "'aquelas pessoas' (referindo-se à família biológica de sua filha) só vão querer tirar vantagem de você".

A dificuldade que os adotados dizem ter enfrentado na sua busca por documentos junto às autoridades públicas alimenta sua suspeita de uma colaboração tácita entre o que veem como as partes mais influentes do processo: administradores e pais adotivos. Tal colaboração é confirmada na história relatada por certa mãe adotiva à pesquisadora Cecília Costa:16 "Teve um senhor que trabalhava no Juizado que nos perguntou a respeito dos documentos. Falamos que preferíamos que nada constasse em papel para evitar constrangimentos futuros. Ele nos deu razão e disse que faria sumir toda a documentação".

Costa também aprendeu de suas informantes como os próprios juízes, para tranquilizar os pais adotivos, podiam "rasgar" os documentos originais da criança. Ou podiam 
17 Ver também ABREU, 2002.

instruir os pais no artifício de "matar" o filho, conseguindo um atestado falso de óbito para que a criança nascesse de novo sem nenhum registro de conexão com os seus pais originais. ${ }^{17}$

Nesse sentido, existe um detalhe relevante nos processos jurídicos que analisamos. Quando se tratava de adoções intrafamiliares (por exemplo, de um pai viúvo para sua irmã), os processos pareciam permanecer intactos. Quando se tratava de adoções entre desconhecidos ostensivamente entre pessoas de condição socioeconômica muito diferente -, documentos sumiam dos arquivos, "desentranhados" a pedido oficial. Foi o que ocorreu no caso de Nilce. Conforme o processo judicial iniciado em 1965, a menina vivia há vários anos com certo casal quando esse, "tratando-a e considerando como se filha fosse, dando à mesma menor o carinho que the faltou por parte de sua mãe", pediu para adotá-la. Quando o tribunal solicitou alguma manifestação da mãe biológica, o requerente (pai adotivo) disse que se tratava de uma mulher que "sempre levou vida irregular e que atualmente se acha em lugar incerto e não sabido". Quando o tribunal teimou em encontrar a mãe, o requerente apareceu com uma certidão do Hospital Psiquiátrico São Pedro, dizendo que certa mulher (com quase o mesmo nome da genitora em questão) sofria de esquizofrenia. Com isso, o tribunal concedeu a adoção sem ouvir a mãe. Misteriosamente, através do pedido judicial de desentranhamento, dois documentos foram subtraídos do processo logo depois da sentença: o Termo de Guarda e o Termo de Entrega de Menor, nos quais seria possível ver a data e, eventualmente, as condições nas quais a criança chegara à casa dos recorrentes, e o atestado do Hospital quanto à saúde mental da mãe. Será que, tal como no caso relatado por Costa, esses pais não foram instruídos pelos funcionários do tribunal a dar sumiço nos documentos? $\mathrm{Na}$ eventualidade de o filho descobrir que era adotado, seria preferivel tornar esse conhecimento inoperante, destruindo toda pista que pudesse levar à família original.

\section{Disputas de autoridade}

Existe uma última hipótese para explicar por que é tão difícil para os adotados encontrar os registros que pudessem documentar suas adoções: o medo dos que intermediaram o processo de serem acusados de "trafico de bebês". Certos observadores argumentam que foi só nos anos 1980, com a chegada de estrangeiros à procura de crianças adotáveis, que a adoção passou a angariar a

${ }^{18}$ ABREU, 2002. atenção de juristas. ${ }^{18}$ Uma série de escândalos (alguns comprovados, outros não) eclodiram com a indignação 
19 SANTA CASA DE MISERICÓRDIA, 1951 , p. 122.

${ }^{20}$ Cabe sublinhar a colaboração da Santa Casa com outras instituições, tais como o Serviço Social de Menores (Sesme), criado em 1945, a Secretaria de Estado de Trabalho e Assistência Social, criada (com nome levemente diferente) em 1958, e órgãos como a LBA e várias instituições católicas.

21 SANTA CASA DE MISERICÓRDIA, 1953 , p. $83-85$.

22 SANTA CASA DE MISERICÓRDIA, 1955, p. 75. dirigida contra a "venda de bebês", isto é, as altas somas de dinheiro pagas por estrangeiros a advogados e agências locais. Mas, ao que tudo indica, esses escândalos envolviam tensões de longa data entre as diferentes autoridades que lidavam com a infância desvalida.

No Rio Grande do Sul, a assistência social tinha sido historicamente realizada em grande medida por religiosos com auxílio de leigos. Contudo, em meados do século XX, já havia claros sinais de profissionalização desse setor. Mal tinha sido criado um curso universitário de Serviço Social (1947), quando as primeiras assistentes sociais foram incorporadas ao corpo funcional da Santa Casa de Porto Alegre. No relatório anual de 1951 dessa instituição, o religioso encarregado do setor de "Expostos" escreve com o que parece uma mistura de queixa e louvor:

[...] praticamente inexiste a mordomia de que somos titular, esgotada que está de função, desde que se criou, neste nosocômio, o serviço social-hospitalar, entre cujas tarefas regulamentares se inclui o atendimento social, no mais amplo sentido da expressão, de todas as crianças aqui recolhidas e em que se configure o estado de abandono. ${ }^{19}$

Junto com a introdução de profissionais no campo, vem uma atenção renovada para a legalidade..$^{20}$ Desde 1950, há menção, nos relatório anuais, da necessidade de uma "estreita colaboração" com o Juizado de Menores, tacitamente reconhecido como autoridade superior à própria Santa Casa. As assistentes sociais passam a incluir nos relatórios da "Mordomia dos Expostos" um tipo de prestação de contas de seu trabalho. Aparecem estatísticas não só sobre crianças abandonadas, mas também sobre pedidos de colocação familiar, pesquisas domiciliares e colocações realizadas etc. As diferentes medidas passam a ser normatizadas, com clara distinção, por exemplo, entre colocações provisórias (usadas para "débeis físicos ou mentais, abandonados por apenas um dos progenitores, enquanto $o$ outro necessita de trabalho, cujos pais estão em tratamento médico aguardando internação") e definitivas ("usadas nos casos em que a criança é reconhecidamente abandonada e está em boas condições físicas"). ${ }^{21}$ Até meados da década, esse serviço passa a realizar estudos sociais sistemáticos nas famílias (tanto da mãe quanto do lar substituto), reivindicando também um papel ativo na prevenção do abandono. Esclarece-se o intuito da intervenção, "visando manter o binômio mãe-filho", "lutando contra o problema da mãe solteira", procurando "proporcionar às mães meios econômicos, e despertar seu senso de responsabilidade para que possam conservar seus filhos e criá-los". ${ }^{22}$ 
${ }^{23}$ SANTA CASA DE MISERICÓRDIA, 1955, p. 72.

${ }^{24}$ SANTA CASA DE MISERICÓRDIA, 1950 , p. 95.

${ }^{25}$ Viviana ZELIZER, 1985.

${ }^{26}$ Maria Bernadete RODRIGO, 1983.

${ }^{27}$ CECRIFE, [s.d.].
Contudo, o que interessa mais nesses relatórios é o aparecimento, em 1957, de uma nova categoria na lista de estatísticas - "O Serviço Social registrou [...] 116 famílias que solicitaram crianças do Berçário para fins de adoção". ${ }^{23}$ Antes, já havia um reconhecimento tácito do grande número de demandas evidenciado, por exemplo, no relatório de 1950: "norma é [...] estimular os casais a terem filhos próprios, orientando-os no sentido de, para isso, esgotarem os recursos de que dispõe a medicina, e só concordando com a entrega da criança quando tal fato se tenha comprovado". ${ }^{24}$ Mas, a partir de certo momento, a demanda passa a ser quantificada, revelando claramente que é várias vezes maior que a oferta de crianças adotáveis.

Historiadores sugerem que essa demanda é relativamente recente, surgindo só nos últimos cem anos da história ocidental. Tradicionalmente, não era incomum encontrar crianças "em circulação", isto é, que se criavam entre as casas de diferentes adultos que fossem vizinhos, parentes ou empregadores. Mas, a partir de certo momento, casais das camadas médias, enfrentando dificuldades para engravidar, passaram a procurar "completar" sua família pela adoção. A criança que, em época anterior vivia com o status ambíguo de "cria de casa", passa a ser tratada "como se filho fosse". Procuram-se em particular recém-nascidos, de pele clara e em bom estado de saúde. E é justamente essa procura, constituindo certo tipo de criança em objeto precioso, que engendra o fantasma de um "mercado" de bebês. ${ }^{25}$

Nas cidades brasileiras, a demanda crescente por bebês ocorre numa época de intensa urbanização. Instituições de caridade que, antes, cuidavam apenas de "órfãos" agora voltam suas energias para o que parece ser um número cada vez maior de mulheres grávidas desamparadas. Um levantamento de 1979 mostra meia dúzia de "casas para a mãe solteira" só em Porto Alegre, com mais vinte casas semelhantes espalhadas pelo interior do estado. ${ }^{26}$ Não há dúvida quanto às motivações cristãs que inspiraram a inauguração de boa parte dessas obras. A irmã luterana que em 1980 fundou um lar para gestantes frisa que ela e as voluntárias de sua congregação ficaram condoídas com o grande número de jovens mulheres com recém-nascidos rechaçadas pelas famílias: "não sabiam aonde ir - teriam que voltar para a rua ou para a casa de um patrão que as explorava". Frisa que foi só depois de consultar um primeiro grupo de gestantes, escutando qual a demanda delas, que resolveram montar uma casa que daria orientação médica, formação profissional e abrigo para as mulheres até três meses depois do parto. ${ }^{27}$

Sem dúvida muitas dessas instituições ajudaram a evitar a entrega de bebês em adoção. Entretanto, 
${ }^{28}$ FONSECA, 2006

${ }^{29}$ ABREU, 2002.
${ }^{30}$ ABREU, 2002, p. 67. especialmente com o início da adoção internacional, a procura por crianças adotivas não parava de exercer pressões no sentido contrário. ${ }^{28} \mathrm{Abreu}^{29}$ descreve como, num primeiro momento, damas de alta sociedade, conhecidas por suas atividades filantrópicas, se orgulhavam de seu papel de "cegonha". Consideravam que estavam fazendo o bem para todos os envolvidos: davam socorro a gestantes, salvavam bebês da miséria e alegravam casais que tanto queriam um filho. Entretanto, nos anos 1980, o campo, que até então tinha sido da alçada de organizações religiosas e filantrópicas, passou a ser visitado por advogados que podiam ganhar confortavelmente a vida intermediando adoções. Uma vez contaminada pela possibilidade de dinheiro grosso, a adoção passou a ser assombrada pelo fantasma do "tráfico". Voavam boatos de que tal orfanato "vendia" bebês por Cr\$1 $20.000,00$ (ou US\$ 50.000, o que soava mais sinistro ainda). A partir daí, praticamente todas as instituições que lidavam com bebês de mães pobres passaram a ser suspeitas.

Assim, houve, a partir do fim da década, uma debandada de filantropos que se deslocaram para atividades menos controvertidas, as que não colocariam em risco sua reputação de benfeitores. Mas, especialmente nas congregações religiosas, algumas pessoas persistiam no seu trabalho com gestantes, apesar das possíveis críticas ou da perda de prestígio. Certa freira superiora de uma congregação prestigiosa entrevistada por Abreu conta que foi só "por amor das crianças" e "pela graça de Deus" que ela e as outras irmãs continuaram tanto tempo com suas atividades, apesar das humilhações sofridas (incluindo a fiscalização policial). "Para a superiora, o 'golpe mais forte' partiu da própria congregação, que lhe pediu que parasse definitivamente com as adoções, pois seu trabalho estava 'maculando' o nome da entidade". ${ }^{30}$

Diante de tal desfecho, não é surpreendente que as instituições relutem ainda hoje em reabrir esse capítulo de sua história. Se alguns administradores já sentem o compromisso de guardar o sigilo por respeito aos termos do acordo realizado anos atrás - seja com as mães de nascimento, seja com os pais adotivos -, muitos outros rechaçam qualquer publicidade por medo de serem associados ao tráfico de bebês. Assim, os arquivos daqueles anos continuam "sumidos", inacessíveis tanto aos adotados quanto aos próprios pesquisadores.

\section{Considerações finais}

Voltamos por fim às pessoas que se manifestavam através da associação de filhos adotivos. No site da 
31 FONSECA, 2010.

associação constam não só centenas de cartas de jovens que, tal como Sônia, querem "entender" as circunstâncias de seu abandono, mas há também diversos apelos das próprias mães que procuram qualquer informação: "Faz anos que venho procurando minha filha, não quero prejudicála, somente quero conhecê-la nem que for de longe. Se ela já sabe que é adotada, quero pedir perdão, contar a minha história e não atrapalhar a vida dela, quero de coração conhecer minha filha".

A ironia é que, apesar de a Nova Lei de Adoção ampliar as possibilidades de reencontro, os obstáculos à troca mútua de informações entre uma pessoa adotada e sua família de origem continuam enormes. ${ }^{31}$

Resta como saldo de nossas pesquisas a convicção de que as "mães abandonantes" compõem uma das categorias mais esquecidas da história. Se não é possível reverter certas perdas de épocas passadas, a experiência de tantas mulheres e seus filhos deve servir como lição para não se repetirem os mesmos erros, perpetuando as histórias de injustiça.

\section{Referências}

ABREU, Domingos. No bico da cegonha: histórias de adoção e da adoção internacional no Brasil. Rio de Janeiro: Relume Dumará, 2002.

AYRES, Lygia S. M. Adoção: de menor a criança, de criança a filho. Curitiba: Jurua, 2008.

CARP, E. Wayne. Family Matters: Secrecy and Disclosure in the History of Adoption. Cambridge: Harvard Univ. Press, 1998.

CAULFIELD, Sueann. Em defesa da honra: moralidade, modernidade e nação no Rio de Janeiro, 1918-1940. Campinas: Unicamp, 2000.

CECRIFE. Novo jeito de trabalhar: multiplicando o cuidado e a paz. Porto Alegre: Cecrife, [s.d.].

COSTA, Cecília. Os "filhos do coração": adoção em camadas médias brasileiras. Tese (Doutorado em Antropologia Social) - Museu Nacional, Universidade Federal do Rio de Janeiro, 1988.

DÉCADA DE 50. A gravidez da Rainha do Rádio. 24 ago. 2006. Disponível em: <http://decadade50.blogspot.com /2006/08/gravidez-da-rainha-do-rdio.html> . Acesso em: 14 out. 2011.

EMILINHA BORBA. Disponível em: <http://www.emilinhaborba. com.br/ebdiario.htm > . Acesso em: 14 out. 2011.

ESTEVES, Martha. Meninas perdidas: os populares e o cotidiano do amor no Rio de Janeiro da Belle Epoque. Rio de Janeiro: Paz e Terra, 1989. 
FONSECA, Claudia. "DNA e paternidade: a certeza que pariu a dúvida". Revista Estudos Feministas, v. 12, n. 2, p. 1334, 2005. . 'Uma virada imprevista: o 'fim' da adoção internacional no Brasil". Dados, v. 49, n. 1, p. 41-66, 2006.

. "Abandono, adoção e anonimato: questões de moralidade materna suscitadas pelas propostas legais de 'parto anônimo'”. Sexualidade, Saúde, Sociedade Revista Latino-Americana, n. 1, p. 30-62, 2009.

. "Direito às origens: segredo e desigualdade no controle de informações sobre a identidade pessoal". Revista de Antropologia, v. 53, n. 2, p. 493-526, 2010.

MARCILIO, Maria Luiza. "A roda dos expostos e a criança abandonada na história do Brasil, 1726-1950". In: FREITAS, Marcos Cezar de. (Org.). História social da infância no Brasil. São Paulo: Cortez, 1997. p. 51-76.

MODELL, Judith S. A Sealed and Secret Kinship: The Culture of Policies and Practices in American Adoption. New York: Berghahn Books, 2002.

MOTTA, Maria Antonieta Pisano. Mães abandonadas: a entrega de um filho em adoção. São Paulo: Cortez, 2005.

MOTTA-MAUÉS, Maria Angelica; IGREJA, Daniele G. L.; DANTAS, Luisa S. "De casa em casa, de rua em rua... Na cidade: circulação de crianças, hierarquias e espaços sociais". Antropolítica, Universidade Federal Fluminense, v. 26, p. 63-82, 2009.

OUELLETTE, Françoise-Romaine. "The Social Temporalities of Adoption and the Limits of Plenary Adoption." In: MARRE, Diana; BRIGGS, Laura (Ed.). International Adoption: Global Inequalties and the Circulation of Children. New York: New York University Press, 2009. p. 69-86.

PEDRO, Joana Maria et al. (Org.). "Mulheres, memórias e experiências...: usos e disputas sobre o controle e autonomia do corpo feminino". In: . Práticas proibidas: práticas costumeiras de aborto e infanticídio no século XX. Florianópolis: Cidade Futura, 2003. p. 155-168.

PRIORE, Mary del (Org.). História do amor no Brasil. São Paulo: Contexto, 2005.

RODRIGO, Maria Bernadete. As entidades assistenciais do RS. Dissertação (Serviço Social) - Pontifícia Universidade Católica do Rio Grande do Sul, 1983.

SANTA CASA DE MISERICÓRDIA. Relatório anual. Porto Alegre, 1950. Relatório anual. Porto Alegre, 1951.

. Relatório anual. Porto Alegre, 1953.

. Relatório anual. Porto Alegre, 1955.

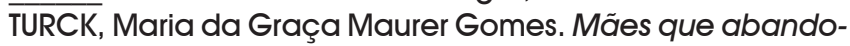
nam: mulheres abandonadas? (Mestrado em Serviço 
Social) - Faculdade de Serviço Social, Pontifícia Universidade Católica do Rio Grande do Sul, 1991.

VENÂNCIO, Renato Pinto (Org.). Uma história social do abandono de crianças: de Portugal ao Brasil - séculos XVIIIXX. Belo Horizonte: PUC Minas; São Paulo: Alameda, 2010.

ZELIZER, Viviana. Pricing the Priceless Child: The Changing Social Values of Children. New York: Basic Books, 1985.

[Recebido em 22 de outubro de 2011 e aceito para publicação em 23 de novembro de 2011]

\begin{abstract}
Abandoning Mothers: Fragments of a Silenced History
Abstract: Inspired in the narratives of members of a Brazilian association of adopted children, this article seeks to put into perspective the stories of women who gave their children in adoption during the mid-20th century. Relying on fragmentary evidence - from interviews with adoptees, letters published on the association's site, judicial archives (for the state of Rio Grande do Sul), annual reports from Porto Alegre's major hospital, and summary information furnished by philanthropic institutions that received unwed mothers decades ago - our analysis addresses two questions framed by the adoptees themselves: why were they given in adoption? And why have the details of their adoptions been systematically silenced by their adoptive parents as well as the intermediaries and state authorities? Our findings suggest diverse possible explanations for giving a child in adoption in Brazil during the years from 1950 to1970: women's lack of legal and economic autonomy, a repressive sexual morality, and geographic and conjugal instability linked to poverty. At the same time, the very difficulties we confronted in encountering information on "abandoning mothers" of the time raise hypotheses on institutional disputes (between adoptive parents, philanthropic institutions and the tribunals) that imposed silence on this particular moment in the evolution of legal adoption in Brazil.
\end{abstract}

Key Words: Foundlings; Maternity; Adoption; Abandoning Mothers. 